\title{
The Relationship Between Plasma Adipsin, Adiponectin, Vaspin, Visfatin, and Leptin Levels with Glucose Metabolism and Diabetes Parameters
}

\author{
(D) Ezel Taşdemir ${ }^{1}$, (D) Abdurrahman Şermet ${ }^{2}$ \\ ${ }^{1}$ Department of Internal Medicine, Medicalpark Hospitals, Antalya, Turkey \\ ${ }^{2}$ Department of Physiology, Dicle University Faculty of Medicine, Diyarbakır, Turkey
}

\begin{abstract}
Introduction: Recently, interesting adipokines have been described that affect glucose metabolism and insulin resistance. However, the relationships between these adipokines and their importance in the pathogenesis of diabetes are contradictory. The aim of the present study was to investigate the relationship between plasma adipsin, adiponectin, vaspin, visfatin, and leptin levels in diabetic rats with liver enzymes related to glucose metabolism and diabetes parameters.

Methods: Wistar albino rats were divided into three groups: control, diabetic control, and treatment groups, each with 7 of them. One group of diabetic rats was orally treated with $200 \mathrm{mg} / \mathrm{kg} /$ day metformin, and the other diabetic group received placebo. After 6 weeks, the animals were sacrificed by cardiac puncture. Glucose, insulin, glycosylated hemoglobin (HbA1c), adipsin, adiponectin, visfatin, vaspin, and leptin levels in blood were measured by enzyme-linked immunosorbent assay (ELISA), and insulin resistance was determined. In liver homogenates, glucose-6-phosphate dehydrogenase (G6PD), glucose-6-phosphatase (G6P-ase), glucokinase, pyruvate kinase (PK), and fructose-1.6-diphosphatase (F1.6DP) activities were measured by ELISA.

Results: Dietary food intake and water consumption, fasting blood glucose and $\mathrm{HbA} 1 \mathrm{c}$ levels, and insulin resistance of diabetic rats were higher than those of the control and treatment groups. Plasma adipsin, adiponectin, vaspin, and leptin levels significantly decreased, and visfatin level increased in diabetic rats. G6PD, glucokinase, and PK activities decreased, whereas G6P-ase and F1.6DP activities increased in diabetic rats. There were a negative correlation between plasma adipsin and adiponectin levels and insulin resistance and a positive correlation between visfatin level and insulin resistance in diabetic rats. In addition, adipsin, adiponectin, and leptin levels were positively correlated with each other and with some liver enzymes.

Discussion and Conclusion: In the diabetic rat model, body weight, glucose metabolism enzymes, insulin sensitivity, and changes in plasma adipsin, adiponectin, vaspin, visfatin, and leptin levels indicate that these adipokines play an important role in the glucose metabolism, insulin resistance, and pathogenesis of diabetes.

Keywords: Adipokines; diabetes; metformin; rat.
\end{abstract}

C urrently, high-calorie diet, fast food dietary habits, and sedentary lifestyle have increased health problems, such as obesity and diabetes. Diabetes, defined as the epidemic of the $21^{\text {st }}$ century by the World Health Organization, disrupts the quality of life by acute and chronic complications. As the cost of treatment is high, it constitutes a signif- icant burden on the economy of underdeveloped and developing countries. In addition, current medical treatment methods do not fully meet the expectations of patients' recovery ${ }^{[1-3]}$. Various theories about the pathogenesis of diabetes have been proposed. However, the pathophysiological mechanisms related to the development and pro-

Correspondence (Illetişim): Ezel Taşdemir, M.D. Medicalpark Hastaneleri, Ic Hastaliklari Anabilim Dali, Antalya, Turkey

Phone (Telefon): +90 5322946617 E-mail (E-posta): dr.ezeldahiliye@hotmail.com

Submitted Date (Başvuru Tarihi): 05.02.2019 Accepted Date (Kabul Tarihi): 13.03.2019

Copyright 2019 Haydarpaşa Numune Medical Journal

OPEN ACCESS This is an open access article under the CC BY-NC license (http://creativecommons.org/licenses/by-nc/4.0/) 
gression of diabetes have not yet been fully elucidated. In the last 30 years, attention has been focused on the role of adipose tissue in inflammatory and metabolic diseases, such as obesity, metabolic syndrome, insulin resistance, and diabetes ${ }^{[4-6]}$.

There are two different adipose tissues in mammalian organisms. Brown adipose tissue with abundant mitochondria is specialized in heat production and thermogenesis. The functional capacity of subcutaneous and visceral adipose tissues is wider [6]. As the largest endocrine organ of the body, it has been found to secrete a large number of bioactive molecules called adipokines. These bioactive substances play a role in many important physiological processes, such as body weight, appetite, glucose, and lipid metabolism and regulation of reproduction, fibrinolysis, angiogenesis, vascular tone control, blood coagulation, and immunity ${ }^{[7,8]}$. The functional impairment of adipose tissue leads to the disruption of the production and secretion of adipokines, and many diseases and its complications occur ${ }^{[8,9]}$. Experimental and clinical evidence has shown that adipokines can be used as biomarkers to diagnose metabolic diseases ${ }^{[9,10]}$. It has been suggested that some adipokines worsen diabetes, whereas others show insulin-like effects, stimulate glucose uptake in the target cells, and reduce insulin resistance ${ }^{[11-18]}$.

Adipsin is the first adipokine defined in 1987. It is then referred to as complement factor D. Serum adipsin levels are lower in patients with diabetes with $\beta$ cell failure. Adipsin therapy in diabetic rats for only a few days has shown significant antidiabetic effects. Therefore, it has been suggested that adipsin is extremely important in maintaining the functioning of the insulin-secreting pancreatic $\beta$ cell ${ }^{[11-13]}$.

Adiponectin is discovered in 1994 as a new protein secreted into the blood from adipose tissue ${ }^{[14]}$. It increases glucose uptake and oxidation of fatty acids in target cells, as well as inhibits hepatic gluconeogenesis. Serum level has been found to be high in patients with diabetes and coronary heart failure. However, some researchers have reported that plasma adiponectin level is low in patients with diabetes ${ }^{[15-21]}$.

Vaspin is first found as a new adipokine in the visceral adipose tissue of insulin-resistant obese rats used as a model for type 2 diabetes. It has been reported that insulin sensitivity is increased in obese mice treated with recombinant vaspin ${ }^{[22-24]}$. Although serum level has been shown to correlate with body fat mass and insulin resistance, vaspin levels have not changed in male and female patients with type 2 diabetes ${ }^{[25]}$.
Visfatin is an adipokine mainly secreted from visceral adipose tissue and acts on the insulin receptor by binding to a different site from where insulin is bound. It has the ability to mimic the effects of insulin and plays an important role in insulin secretion in pancreatic $\beta$ cells ${ }^{[26,27]}$. Plasma visfatin levels have been reported to be high in patients with type 2 diabetes [28-31]. Although visfatin plays an important role in the regulation of insulin secretion, its effects on diabetes risk or on the progression of diabetes have not yet been fully understood ${ }^{[32]}$.

Leptin is an important adipokine secreted mainly from subcutaneous adipose tissue and is known as appetite and satiety-regulating hormone ${ }^{[33]}$. It inhibits insulin and glucagon secretion in the pancreas in addition to increases glucose uptake and fatty acid oxidation in skeletal muscles and improves insulin sensitivity [34]. However, there are contradictions between the results of plasma leptin concentration in patients with type 2 diabetes. Some researchers have reported that leptin levels decrease in patients with type 2 diabetes, whereas others have shown an increase or no difference [35-37].

Since adipose tissue is also an important integrator of glucose metabolism, it is significant to understand its role in the pathogenesis of metabolic diseases, such as obesity and diabetes. Therefore, the information to be obtained may provide a promising technique for a more rational treatment of certain metabolic diseases. The aim of the present study was to determine the changes in plasma adipsin, adiponectin, vaspin, visfatin, and leptin levels in diabetic rats and to investigate the relationship between these adipokines and glucose metabolism and diabetes parameters. In addition, we aimed to collect information on new therapeutic strategies to prevent the development and progression of diabetes.

\section{Materials and Methods}

This research was conducted at the Science Technology Application and Research Center Laboratories of University. The study was approved by the University Animal Research Ethics Committee (Date: 06/12/2017, No: 2017/1417).

\section{Animals}

A total of 28 adult male Wistar albino rats weighing 260 $300 \mathrm{~g}$ were obtained from the Health Sciences Research and Application Center of our university. The animals were kept in stainless steel cages with 12-hour light:12-hour dark rhythm, $22 \pm 2{ }^{\circ} \mathrm{C}$ room temperature, and 55\%-60\% humidity and fed with standard rat chow and water. 


\section{Chemicals, Drugs, and Measurement Kits}

The chemicals (diethyl ether and streptozotocin) used in this research were purchased from Sigma Aldrich (St. Louis, MO, USA). The drug (metformin) was purchased from Bilim Pharmaceuticals (Istanbul, Turkey). Enzyme-linked immunosorbent assay (ELISA) kits used in the measurement of glucose-6-phosphate dehydrogenase (G6PD), glucose-6-phosphatase (G6P-ase), glucokinase, pyruvate kinase (PK), and fructose-1.6-diphosphatase (F1,6DP) activities were purchased from BioVision (CA, USA). Glucose measurement kit was commercially obtained from Sigma Aldrich. Insulin, glycosylated hemoglobin (HbA1c), adipsin, adiponectin, vaspin, visfatin, and leptin ELISA measurement kits were commercially obtained from MyBioSource Inc. (San Diego, CA, USA).

\section{Tools and Equipment}

In the present study, ELISA reader (Multiskan GO; Thermo Scientific, MA, USA), air-cooled microcentrifuge (SL16R; Thermo Scientific, Germany), blood glucose meter and strips (Contour TS; Bayer, Tarrytown, NY, USA), electronic weighing (Sartorius Basic; Göttingen, Germany), precision balance (Precisa XB 220A; Dietikon, Switzerland), homogenizer (IKA Labortechnik Ultra-Turrax T25; Staufen, Germany), deep freezer (Vestel, Turkey), surgical set (Kruuse, Langeskov, Denmark), and automatic pipettes were used.

\section{Diabetic Rat Model}

Body weight of all animals and fasting blood glucose levels were measured before the start of the study. To induce diabetes, streptozotocin $(55 \mathrm{mg} / \mathrm{kg}$ ) prepared in citrate buffer (0.1 M, pH 4.5) was injected intraperitoneally (IP) in a single dose. The control group was treated only with placebo (citrate buffer) IP. Fasting blood glucose was measured in blood samples obtained from the tail veins of rats $48 \mathrm{~h}$ after streptozotocin injection. Rats with fasting blood glucose levels of $\geq 300 \mathrm{mg} / \mathrm{dl}$ were included in the diabetic group.

\section{Experimental Groups}

Wistar albino rats were divided into three groups, each with seven animals, without any significant difference in body weight:

1. Control group: This group was fed with water and standard laboratory rat chow for 6 weeks without restriction.

2. Diabetic control group: Seven diabetic rats in this group were fed as in the control group and did not receive any treatment.
3. Metformin group: Seven diabetic rats were treated intragastrically with metformin $200 \mathrm{mg} / \mathrm{kg} /$ day for 6 weeks. Metformin dose was adjusted every week according to changes in animals' body weights.

\section{Finalizing the Research}

After 6 weeks, after fasting for $12 \mathrm{~h}$, the anterior abdominal wall was opened with an incision under ether anesthesia. Their livers were removed, washed with $0.9 \%$ cold saline, and stored at $-80^{\circ} \mathrm{C}$ until the measurement day to determine the levels of glucose metabolism-related enzymes.

\section{Diabetes Parameters}

Fasting blood glucose was evaluated photometrically by the enzymatic kit obtained from Sigma Aldrich. Serum insulin and $\mathrm{HbA1c}$ levels were estimated using rat ELISA assay kits.

Insulin resistance was calculated as homeostatic model assessment of insulin resistance (HOMA-IR). HOMA is a method for assessing $\beta$ cell function and IR from basal (fasting) glucose and insulin or C-peptide concentrations. The formula is calculated as follows: HOMA-IR=[fasting glucose $(\mathrm{nmol} / \mathrm{l}) \times$ fasting insulin $(\mu \mathrm{U} / \mathrm{l})] / 22.5$.

\section{Evaluation of Plasma Levels of Selected Adipokines}

The levels of plasma adipsin, adiponectin, vaspin, visfatin, and leptin were measured by immunoenzymatic methods using specific ELISA kits (MyBioSource).

\section{Preparation of Liver Homogenates and Determination of Enzyme Activities}

To prepare the homogenate, $9 \mathrm{ml}$ of phosphate buffered saline was added to $1 \mathrm{~g}$ of liver tissue and was crushed with a cooled mechanical homogenizer at $1200 \mathrm{rpm}$ for $5 \mathrm{~min}$. After centrifugation, supernatants were obtained to determine enzyme activities. To evaluate the supernatant protein content, we preferred to use the Lowry method as modified by Hartree [38]. G6PD, G6P-ase, glucokinase, PK, and F1.6DP activities in the supernatants were measured by appropriate rat ELISA kits at the University Science and Technology Application and Research Center Laboratory.

\section{Statistical Analysis}

Statistical evaluations of the data were performed using SPSS version 20.0 package program (SPSS Inc., Chicago, IL, USA). All results were expressed as mean \pm standard deviation. Since the number of data in each group was $<30$, 
Table 1. Daily food intake and water consumption for 3 weeks in all animals

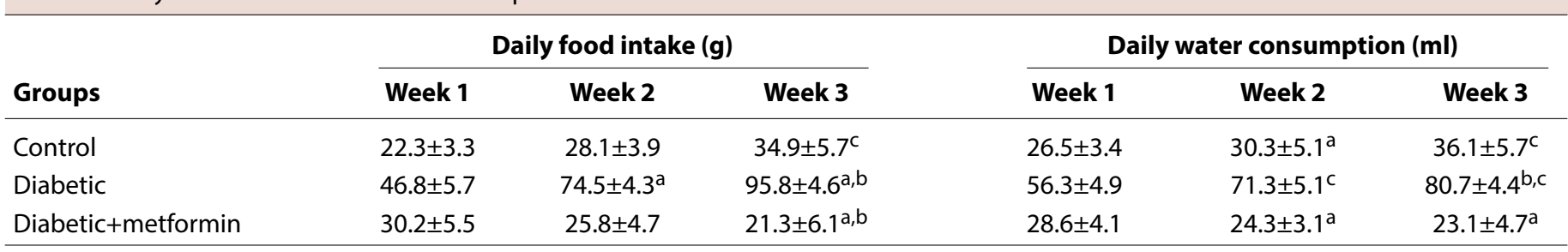

All data are presented as mean \pm SEM of the indicated number of rats $(n=7) ;{ }^{a} p<0.05 ;{ }^{c} p<0.001 ;$ compared with week 1 values; ${ }^{b} p<0.05 ;$ compared with week 2 values.

the findings were evaluated by non-parametric statistical analysis methods. Mann-Whitney $U$ test was used for the analysis of independent groups with two groups. KruskalWallis ANOVA test was used in the analysis of independent groups with more than two groups for non-parametric tests. Wilcoxon matched pairs test was used in the analysis of dependent groups with two groups. Spearman's non-parametric correlation test was used to examine the relationship between the parameters. A $p$ value $<0.05$ was considered significant.

\section{Results}

\section{Body Weight Changes, Food, and Water Consumption}

The increase in food and water consumption in normal rats was accompanied by an increase of $24.81 \%$ in body weight at the end of week 3 . In diabetic rats, the increase in food intake starting on week 1 continued to increase further toward the end of the experiment. However, the body weight of diabetic rats decreased by $5.42 \%$ on week $1,12.27 \%$ on week 2 , and $23.42 \%$ on week 3 . Metformin treatment significantly reduced food and water consumption in diabetic rats with adverse appetite-reducing effects. However, the increase in body weight of animals remained well below healthy controls (Tables 1, 2).

Table 2. Weekly change in body weight (g) over 3 weeks in all groups

\begin{tabular}{lccc}
\hline Weeks & \multicolumn{3}{c}{ Groups } \\
\cline { 2 - 4 } & Control & Diabetic & $\begin{array}{c}\text { Diabetic+ } \\
\text { metformin }\end{array}$ \\
\hline Baseline & $270 \pm 5.2$ & $277 \pm 6.3$ & $281 \pm 5.7$ \\
Week 1 & $291 \pm 4.8^{\mathrm{a}}$ & $268 \pm 5.7^{\mathrm{a}}$ & $277 \pm 4.4$ \\
Week 2 & $315 \pm 6.4^{\mathrm{b}}$ & $243 \pm 6.4^{\mathrm{b}, \mathrm{d}}$ & $280 \pm 3.9$ \\
Week 3 & $337 \pm 6.2^{\mathrm{c}, \mathrm{d}}$ & $210 \pm 6.2^{\mathrm{c}, \mathrm{d}, \mathrm{e}}$ & $284 \pm 4.8$ \\
Changes (\%) & +24.81 & -23.42 & +1.07 \\
\hline
\end{tabular}

All data are presented as mean \pm SEM of the indicated number of rats $(n=7)$; ${ }^{a} p<0.05,{ }^{b} p<0.01,{ }^{c} p<0.001$, compared with the baseline value; ${ }^{d} p<0.01$, compared with week 1 values; ${ }^{e} p<0.05$, compared with week 2 values.

\section{Glycemic Parameters}

At the end of week 6 , the average fasting blood glucose level increased approximately fourfold in diabetic rats compared with healthy control values. Metformin treatment provided an improvement of approximately $64 \%$ in blood glucose levels. Plasma insulin levels in diabetic rats decreased by $45 \%$ compared with the control value, whereas $\mathrm{HbA1C}$ and insulin resistance (HOMA-IR) increased by approximately $100 \%$ and were twice the normal value. Metformin treatment partially improved the plasma insulin levels of diabetic rats. In addition, a significant improvement in $\mathrm{HbA1c}$ was observed in metformin-treated rats, and there was a slight decrease in insulin resistance (Table 3 ).

\section{Plasma Levels of Adipokines}

As shown in Table 4, plasma adipsin, adiponectin, vaspin, and leptin levels were significantly decreased in diabetic rats compared with control values, whereas visfatin levels increased. Treatment with metformin for 6 weeks significantly decreased the visfatin plasma level of diabetic rats compared with untreated animals, whereas other adipokines, such as adipsin, adiponectin, vaspin, and leptin, significantly increased plasma levels.

Table 3. Fasting blood glucose, insulin, HbA1c, and HOMA-IR levels as an indicator of insulin resistance

\begin{tabular}{lccc}
\hline Parameters & \multicolumn{3}{c}{ Groups } \\
\cline { 2 - 4 } & Control & Diabetic & $\begin{array}{c}\text { Diabetic+ } \\
\text { metformin }\end{array}$ \\
\hline Glucose $(\mathrm{mg} / \mathrm{dl})$ & $105.2 \pm 4.8$ & $415.3 \pm 13.2^{\mathrm{a}}$ & $294.1 \pm 9.7^{\mathrm{a}, \mathrm{b}}$ \\
Insulin $(\mu \mathrm{U} / \mathrm{ml})$ & $13.3 \pm 1.1$ & $7.4 \pm 1.2^{\mathrm{a}}$ & $9.8 \pm 0.9^{\mathrm{a}, \mathrm{c}}$ \\
HbA1c $(\%)$ & $6.4 \pm 0.2$ & $13.1 \pm 0.3^{\mathrm{a}}$ & $8.3 \pm 0.3^{\mathrm{b}, \mathrm{d}}$ \\
HOMA-IR & $3.34 \pm 0.15$ & $7.60 \pm 0.18^{\mathrm{a}}$ & $7.11 \pm 0.1^{\mathrm{c}, \mathrm{a}}$
\end{tabular}

The HOMA-IR was calculated as shown in the formula: HOMA-IR=[fasting insulin $(\mu \mathrm{U} / \mathrm{l}) \times$ fasting glucose $(\mathrm{nmol} / \mathrm{l})] / 22.5$; All data are presented as mean \pm SEM of the indicated number of rats $(n=7) ;{ }^{a} p<0.001,{ }^{d} p<0.05$, compared with the control group; ${ }^{b} p<0.001, c p<0.05$, compared with the diabetic group; HbA1c, glycosylated hemoglobin; HOMA-IR, homeostatic model assessment of insulin resistance. 


\section{Liver Enzymes}

G6P-ase and F1,6DP levels increased significantly, whereas liver G6PD, glucokinase, and PK levels decreased in diabetic rats. Significant improvements were found in liver enzymes that affect glucose metabolism in diabetic rats treated with metformin. Metformin treatment significantly inhibited both low G6PD, glucokinase, and PK levels and high G6P and F1.6DP levels (Table 5).

\section{Relationships Between Adipokines and Glucose Metabolism and Diabetes}

We have tested the relationships between plasma adipsin, adiponectin, vaspin, visfatin, and leptin levels with each other and with glucose metabolism enzymes and HOMA-IR (as an index of insulin resistance). There was no correlation

Table 4. Plasma adipsin, adiponectin, vaspin, visfatin, and leptin levels in control, diabetic, and metformin-treated diabetic rats

\begin{tabular}{lccc}
\hline & \multicolumn{3}{c}{ Groups } \\
\cline { 2 - 4 } Parameters & Control & Diabetic & $\begin{array}{c}\text { Diabetic+ } \\
\text { metformin }\end{array}$ \\
\hline Adipsin $(\mathrm{ng} / \mathrm{ml})$ & $8.86 \pm 1.11$ & $5.58 \pm 0.31^{\mathrm{a}}$ & $6.62 \pm 0.77^{\mathrm{b}}$ \\
Adiponectin $(\mathrm{mg} / \mathrm{l})$ & $5.56 \pm 0.28$ & $4.62 \pm 0.34^{\mathrm{a}}$ & $5.62 \pm 0.29^{\mathrm{a}}, \mathrm{b}$ \\
Vaspin $(\mathrm{ng} / \mathrm{l})$ & $686.31 \pm 11.65$ & $578.36 \pm 43.11^{\mathrm{a}}$ & $591.95 \pm 70.78^{\mathrm{b}}$ \\
Visfatin $(\mathrm{ng} / \mathrm{ml})$ & $45.32 \pm 1.16$ & $53.41 \pm 3.54^{\mathrm{d}}$ & $49.0 \pm 2.74^{\mathrm{c}}$ \\
Leptin $(\mathrm{pg} / \mathrm{ml})$ & $369.77 \pm 27.37$ & $303.16 \pm 37.18^{\mathrm{a}}$ & $370.69 \pm 19.80^{\mathrm{b}}$ \\
\hline
\end{tabular}

All data are presented as mean \pm SEM of the indicated number of rats $(n=7)$; ${ }^{a} p<0.01,{ }^{d} p<0.05$, compared with the control group; ${ }^{b} p<0.01,{ }^{c} p<0.05$, compared with the diabetic group.

Table 5. Liver enzymes in normal, diabetic, and metformin-treated rats

\begin{tabular}{|c|c|c|c|}
\hline \multirow[b]{2}{*}{ Parameters } & \multicolumn{3}{|c|}{ Groups } \\
\hline & Control & Diabetic & $\begin{array}{l}\text { Diabetic+ } \\
\text { metformin }\end{array}$ \\
\hline G6PD (ng/g protein) & $520.3 \pm 13.8$ & $279.6 \pm 10.2^{a}$ & $392.4 \pm 11.8^{a, b}$ \\
\hline $\begin{array}{l}\text { G6P-ase } \\
\text { (ng/g protein) }\end{array}$ & $1010.5 \pm 58.7$ & $2253.42 \pm 75.1^{a}$ & $1172.8 \pm 82.4^{b}$ \\
\hline $\begin{array}{l}\text { Glucokinase } \\
\text { ( } \mathrm{gg} / \mathrm{mg} \text { protein) }\end{array}$ & $275.4 \pm 10.3$ & $141.3 \pm 9.7^{a}$ & $263.8 \pm 12.4^{b}$ \\
\hline PK ( $\mu \mathrm{g} / \mathrm{mg}$ protein) & $205.6 \pm 10.3$ & $89.3 \pm 11.5^{a}$ & $172.4 \pm 9.2 b^{b, c}$ \\
\hline $\begin{array}{l}\text { F1.6DP } \\
\text { ( } \mu \mathrm{mol} / \mathrm{g} \text { protein) }\end{array}$ & $482.1 \pm 11.2$ & $794.6 \pm 15.4^{a}$ & $621.5 \pm 10.3^{a, b}$ \\
\hline
\end{tabular}

All data are presented as mean \pm SEM of the indicated number of rats $(n=7)$; ap $<0.001, c p<0.05$, compared with the control group; $b p<0.01$, compared with the diabetic group; G6PD, glucose-6-phosphate dehydrogenase; G6P-ase, glucose-6-phosphatase; PK, pyruvate kinase; F1,6DP, fructose-1,6-diphosphatase. between the plasma adipokine levels of control rats. In contrast, plasma adiponectin and leptin levels were correlated in diabetic rats (Fig. 1). A similar relationship was also found between plasma adipsin and leptin levels in diabetic rats treated with metformin (Fig. 2). Some adipokines are associated with insulin resistance (plasma fasting glucose and insulin levels). Plasma adipsin and adiponectin levels were negatively correlated with insulin resistance in diabetic rats

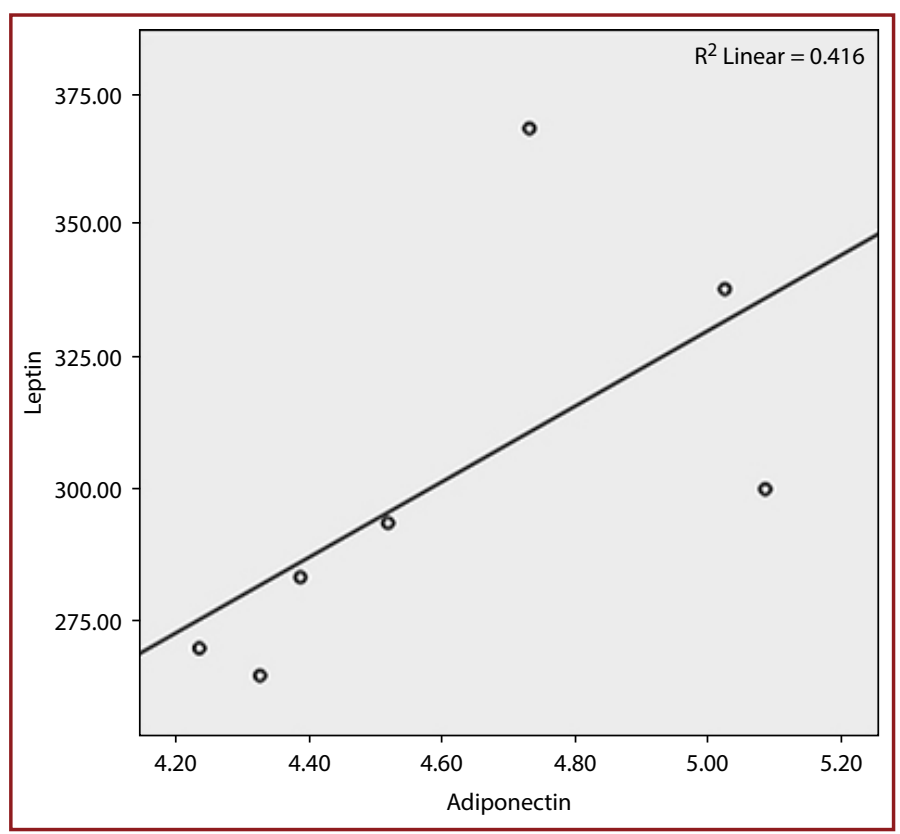

Figure 1. Correlation between plasma adiponectin and leptin level in diabetic rats. $R^{2}=0.416, p<0.05$.

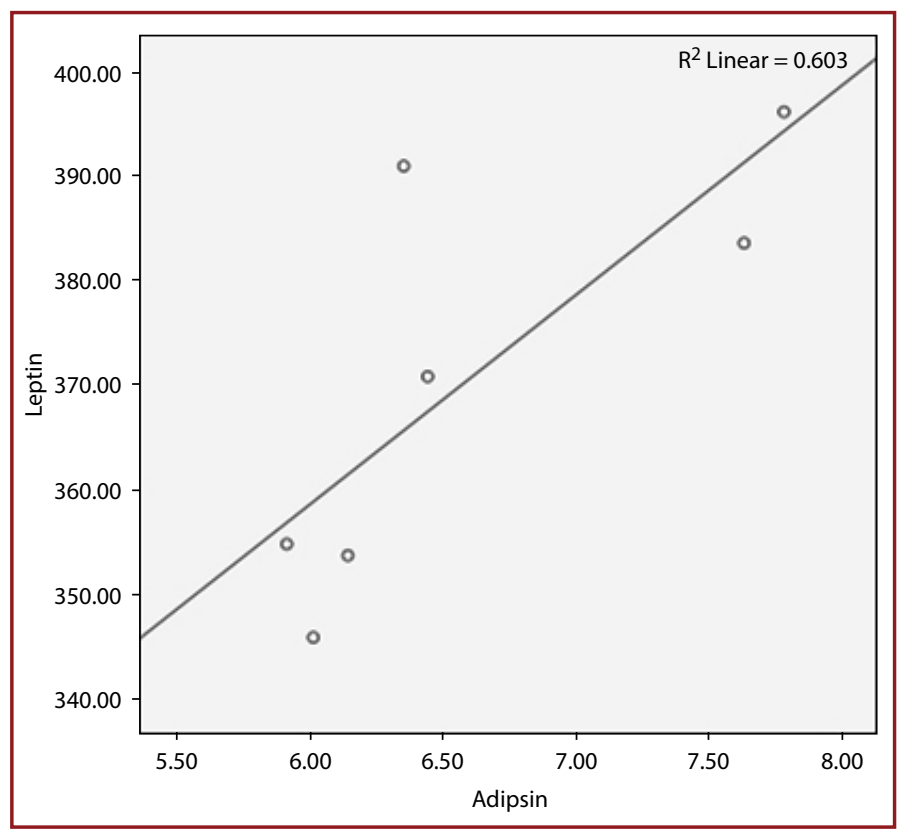

Figure 2. Correlation between plasma adipsin and leptin level in diabetic rats treated with metformin. $R^{2}=0.603, p<0.05$. 
(Figs. 3, 4). In addition, the level of plasma visfatin is related to the enzyme of glucose metabolism in the liver of control and diabetic rats. There was a negative correlation between plasma visfatin levels and liver G6P and F1.6DP in control rats, but there was a positive correlation in diabetic rats (Figs. $5,6)$. The correlation between plasma visfatin and liver G6P levels in control and diabetic rats was not shown in the figure. Correlation coefficients and correlation $p$ values are pre-

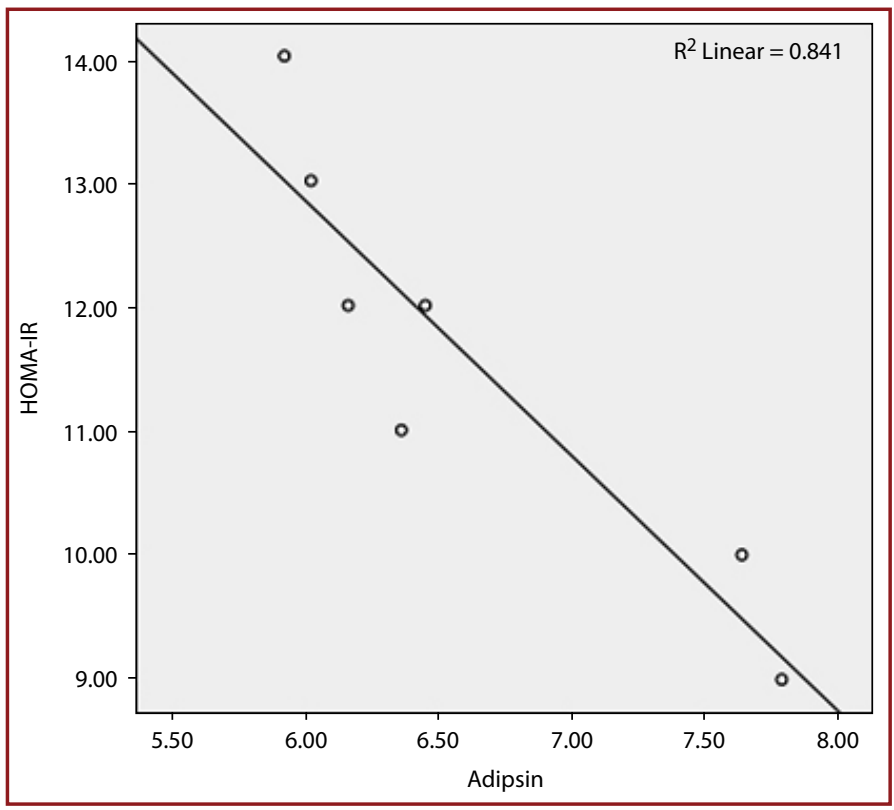

Figure 3. Correlation between plasma adipsin level and insulin resistance (HOMA-IR) in diabetic rats. $\mathrm{R}^{2}=0.841, \mathrm{p}<0.01$. HOMA-IR, homeostatic model assessment of insulin resistance.

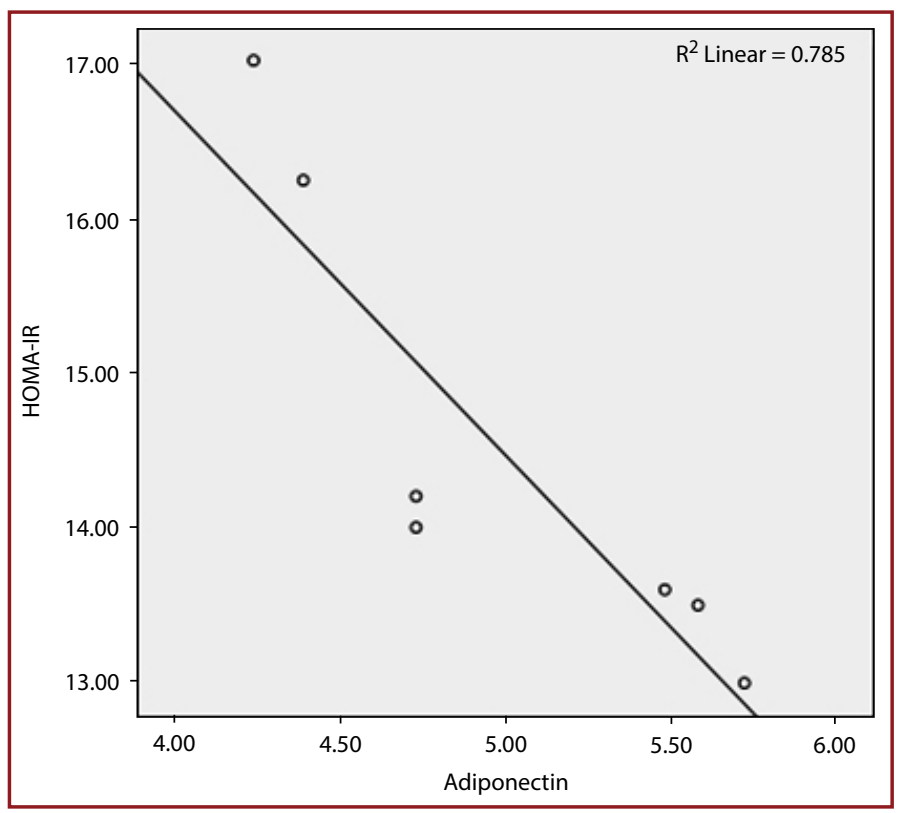

Figure 4. Correlation between plasma adiponectin level and insulin resistance (HOMA-IR) in diabetic rats. $\mathrm{R}^{2}=0.785, \mathrm{p}<0.01$. HOMA-IR, homeostatic model assessment of insulin resistance. sented below. The correlation coefficients between plasma visfatin and liver G6P in control and diabetic animals were $r=-0.792, p<0.05$ and $r=0.821, p<0.05$, respectively.

\section{Discussion}

For many years, fat tissue was believed to be a highly passive lipid accumulation. We have learned that currently, as

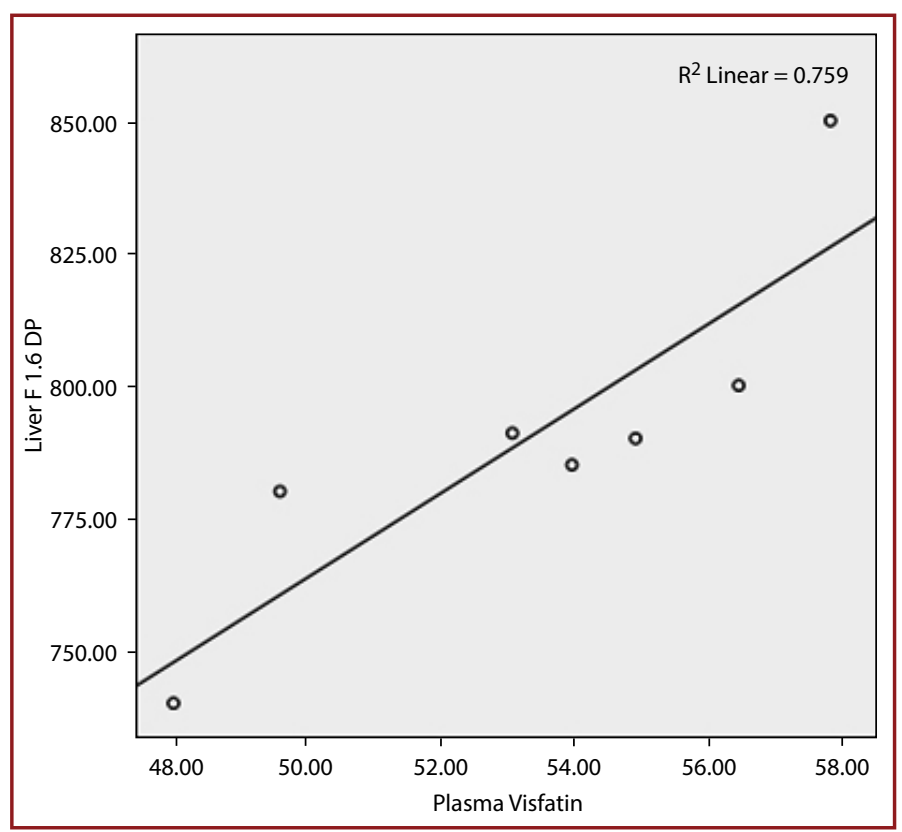

Figure 5. Correlation between plasma visfatin level and liver F1.6DP in diabetic rats. $R^{2}=0.759, p<0.01$. F1.6DP, fructose-1.6-diphosphatase.

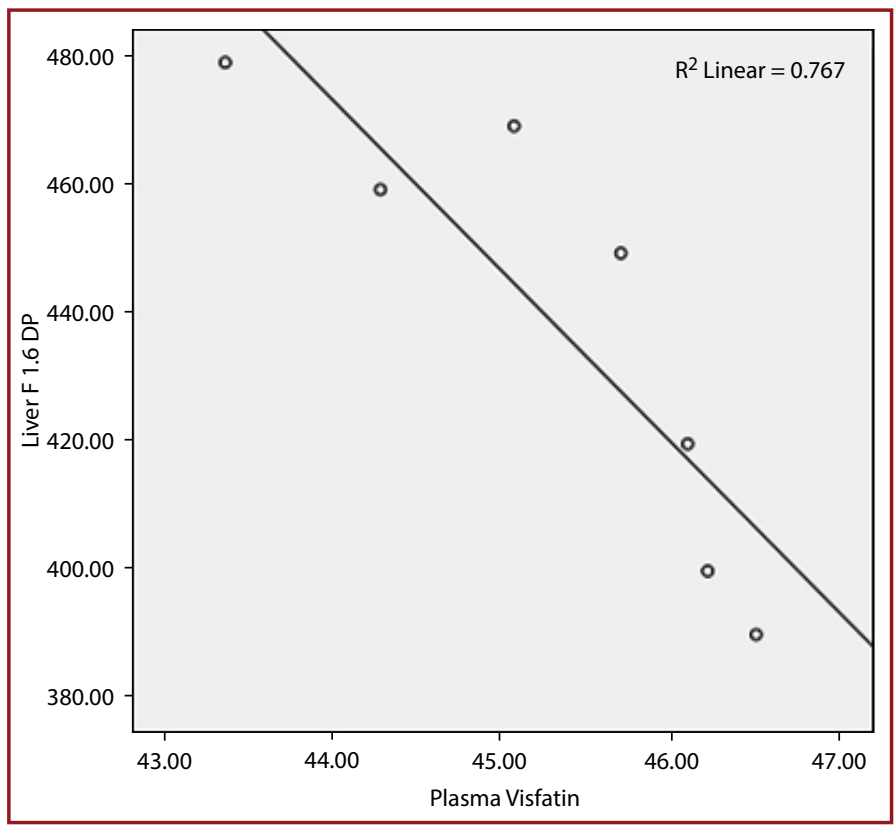

Figure 6. Correlation between plasma visfatin level and liver F1.6DP in control rats. $\mathrm{R}^{2}=0.767, \mathrm{p}<0.01$. F1.6DP, fructose-1.6-diphosphatase. 
a very important endocrine organ, it can synthesize and secrete bioactive molecules called adipokines associated with carbohydrate and lipid metabolism. The list of adipokines is expanding gradually with the great interest and effort of the researchers. Adipokines have autocrine, paracrine, and endocrine effects that regulate insulin sensitivity and many physiological processes. Some adipokines are responsible for the pathogenesis of many metabolic diseases, such as diabetes and its complications ${ }^{[5-9]}$. Adipokines, which are generally proinflammatory, is believed to induce the development and complications of diabetes, whereas antiinflammatory adipokines are estimated to have beneficial or preventive effects on diabetes [7-9, 13, 17-19]. Adipsin, adiponectin, vaspin, visfatin, and leptin are known as adipokines, which increase insulin sensitivity and reduce glucose intolerance ${ }^{[20-24,31-34]}$. However, some experimental results have shown that these adipokines have no beneficial effect on glucose metabolism and insulin resistance ${ }^{[8]}$. In the present study, we found that the plasma adipsin, adiponectin, vaspin, and leptin levels of diabetic rats were lower than those of control and metformin-treated diabetic rats. Many studies have demonstrated that these adipokines have direct or indirect anti-inflammatory and antidiabetic effects, and their plasma levels are low in individuals with type 2 diabetes ${ }^{[19,22,37]}$. Although our findings support the literature knowledge, it is in contrast with the results of some studies. There is no complete agreement between the results of experimental and clinical trials in this subject ${ }^{[25,35] \text {. }}$

We observed significant improvements in plasma adipsin, adiponectin, vaspin, and leptin levels in diabetic rats treated with metformin. Even in previous studies, metformin showed similar effects. The mechanism associated with the role of metformin in the regulation of plasma levels of adipokines with antidiabetic activity is not yet fully understood. It may be speculated that metformin stimulates the secretion of anti-inflammatory and antidiabetic adipokines from adipose tissue. Visfatin is one of the most studied adipokines. It has been proven by many studies that it mimics the effects of insulin. It is surprising that this adipokine plasma level is significantly high in diabetic rats ${ }^{[32]}$. We also found that plasma visfatin levels were increased in untreated and metformin-treated diabetic rats. Plasma visfatin levels were generally found to be high not only in experimental diabetic animal models but also in humans with type 2 diabetes ${ }^{[28]}$.

G6PD, G6P, F1.6DP, glucokinase, and PK are key enzymes in the liver that regulate glucose metabolism. It is known that the enzyme activity responsible for glycolysis and gluconeogenesis changed in the liver of diabetic rats. We also found that G6PD, glucokinase, and PK levels were de- creased, and G6P and F1.6DP levels increased in untreated diabetic rats. Thus, in diabetic rats, on the other hand, an increase in gluconeogenesis in the liver, a condition that limits the consumption of glucose in the liver and in peripheral tissues, has contributed significantly to hyperglycemia. Our results showed that there was a positive correlation between liver G6P levels in diabetic rats despite a negative correlation in control rats. Visfatin increases glucose uptake in peripheral tissues and inhibits glucose release from the liver to the blood ${ }^{[8,32]}$. Although plasma visfatin levels were significantly increased in diabetic rats, liver enzymes responsible for gluconeogenesis remained elevated. Could this be a paradox about the insulin mimicked effect of visfatin? Or could insulin resistance, as well as visfatin resistance, occur in diabetic rats? Some researchers have reported that leptin resistance develops in some obese rats $[8,33]$. In light of this knowledge, it can be considered that any resistance to other adipokines may be in pathological conditions or diseases. It is important to clarify visfatin resistance with regard to the pathogenesis of diabetes.

Recently, the presence of subclinical chronic inflammation in the adipose tissue of individuals with type 2 diabetes and the change in adipocyte metabolism are assumed to play an important role in the pathogenesis of the disease [39]. Impairment in adipose tissue metabolism, particularly a decrease in anti-inflammatory adipokine production or an increase in inflammatory adipokine synthesis, may be one of the major pathophysiological mechanisms of diabetes. Our data show that the plasma levels of adipokines are altered in an experimental diabetic rat model. Adipsin, adiponectin, vaspin, and leptin levels decrease, whereas visfatin levels increase. An increase in visfatin level may be important in limiting diabetes. However, the increase in plasma visfatin did not fully compensate for the attenuation of the effect of insulin sensitizer adipsin, adiponectin, vaspin, and leptin. According to the results of the present study, there is a relationship between plasma adiponectin and visfatin levels with insulin sensitivity and the key enzymes of gluconeogenesis in diabetic rats. In conclusion, the present study showed that some anti-inflammatory adipokines have beneficial effects on insulin sensitivity and glucose metabolism in diabetic rat plasma. Thus, agents capable of increasing the secretion of anti-inflammatory adipokines or reducing the secretion of inflammatory adipokines may be included in new treatment protocols if they have proven useful by adequate clinical trials.

Ethics Committee Approval: This study was performed in the laboratories of the University Science and Technology Application and Research Center after approval from the local ethics committee (Approvel Number: 2017/05). 
Peer-review: Internally peer-reviewed.

Authorship Contributions: Concept: E.T., A.Ş; Design: E.T., A.Ş; Data Collection or Processing: A.Ş; Analysis or Interpretation: E.T., A.Ş; Literature Search: E.T., A.Ş; Writing: E.T

Conflict of Interest: None declared.

Financial Disclosure: The authors declared that this study received no financial support.

\section{References}

1. Sullivan PW, Morrato EH, Ghushchyan V, Wyatt HR, Hill JO. Obesity, inactivity, and the prevalence of diabetes and diabetes-related cardiovascular comorbidities in the U.S., 20002002. Diabetes Care 2005;28:1599-603. [CrossRef]

2. Engelgau MM, Geiss LS, Saaddine JB, Boyle JP, Benjamin SM, Gregg EW, et al. The evolving diabetes burden in the United States. Ann Intern Med 2004;140:945-50. [CrossRef]

3. Watal G, Dhar P, Srivastava SK, Sharma B. Herbal medicine as an alternative medicine for treating diabetes: the global burden. Evid Based Complement Alternat Med 2014;2014:596071.

4. Stumvoll M, Goldstein BJ, van Haeften TW. Type 2 diabetes: principles of pathogenesis and therapy. Lancet 2005;365:1333-46. [CrossRef]

5. Ahima RS. Adipose tissue as an endocrine organ. Obesity (Silver Spring) 2006;14 Suppl 5:242S-9S. [CrossRef]

6. Pfeifer A, Hoffmann LS. Brown, beige, and white: the new color code of fat and its pharmacological implications. Annu Rev Pharmacol Toxicol 2015;55:207-27. [CrossRef]

7. Fasshauer M, Blüher M. Adipokines in health and disease. Trends Pharmacol Sci 2015;36:461-70. [CrossRef]

8. Falcão-Pires I, Castro-Chaves P, Miranda-Silva D, Lourenço AP, Leite-Moreira AF. Physiological, pathological and potential therapeutic roles of adipokines. Drug Discov Today 2012;17:880-9. [CrossRef]

9. Rajkovic N, Zamaklar M, Lalic K, Jotic A, Lukic L, Milicic T, et al. Relationship between obesity, adipocytokines and inflammatory markers in type 2 diabetes: relevance for cardiovascular risk prevention. Int J Environ Res Public Health 2014;11:404965. [CrossRef]

10. Hara K, Horikoshi M, Yamauchi T, Yago H, Miyazaki O, Ebinuma $\mathrm{H}$, et al. Measurement of the high-molecular weight form of adiponectin in plasma is useful for the prediction of insulin resistance and metabolic syndrome. Diabetes Care 2006;29:1357-62. [CrossRef]

11. Cook KS, Min HY, Johnson D, Chaplinsky RJ, Flier JS, Hunt CR, et al. Adipsin: a circulating serine protease homolog secreted by adipose tissue and sciatic nerve. Science 1987;237:402-5.

12. White RT, Damm D, Hancock N, Rosen BS, Lowell BB, Usher $P$, et al. Human adipsin is identical to complement factor $D$ and is expressed at high levels in adipose tissue. J Biol Chem 1992;267:9210-3.

13. Lo JC, Ljubicic S, Leibiger B, Kern M, Leibiger IB, Moede T, et al. Adipsin is an adipokine that improves $\beta$ cell function in diabetes. Cell 2014;158:41-53. [CrossRef]
14. Okamoto $Y$, Arita $Y$, Nishida M, Muraguchi M, Ouchi N, Takahashi $M$, et al. An adipocyte-derived plasma protein, adiponectin, adheres to injured vascular walls. Horm Metab Res 2000;32:47-50. [CrossRef]

15. Kharroubi I, Rasschaert J, Eizirik DL, Cnop M. Expression of adiponectin receptors in pancreatic beta cells. Biochem Biophys Res Commun 2003;312:1118-22. [CrossRef]

16. Weyer C, Funahashi T, Tanaka S, Hotta K, Matsuzawa Y, Pratley $\mathrm{RE}$, et al. Hypoadiponectinemia in obesity and type 2 diabetes: close association with insulin resistance and hyperinsulinemia. J Clin Endocrinol Metab 2001;86:1930-5. [CrossRef]

17. Kubota N, Terauchi Y, Yamauchi T, Kubota T, Moroi M, Matsui J, et al. Disruption of adiponectin causes insulin resistance and neointimal formation. J Biol Chem 2002;277:25863-6. [CrossRef]

18. Hotta K, Funahashi T, Arita Y, Takahashi M, Matsuda M, Okamoto $Y$, et al. Plasma concentrations of a novel, adiposespecific protein, adiponectin, in type 2 diabetic patients. Arterioscler Thromb Vasc Biol 2000;20:1595-9. [CrossRef]

19. Spranger J, Kroke A, Möhlig M, Bergmann MM, Ristow M, Boeing $\mathrm{H}$, et al. Adiponectin and protection against type 2 diabetes mellitus. Lancet 2003;361:226-8. [CrossRef]

20. Yamauchi T, Kamon J, Waki H, Terauchi Y, Kubota N, Hara K, et al. The fat-derived hormone adiponectin reverses insulin resistance associated with both lipoatrophy and obesity. Nat Med 2001;7:941-6. [CrossRef]

21. Awazawa M, Ueki K, Inabe K, Yamauchi T, Kaneko K, Okazaki $Y$, et al. Adiponectin suppresses hepatic SREBP1c expression in an AdipoR1/LKB1/AMPKdependent pathway. Biochem Biophys Res Commun 2009;382:51-6. [CrossRef]

22. Dimova R, Tankova T. The role of vaspin in the development of metabolic and glucose tolerance disorders and atherosclerosis. Biomed Res Int 2015;2015:823481. [CrossRef]

23. Chang HM, Lee HJ, Park HS, Kang JH, Kim KS, Song YS, et al. Effects of weight reduction on serum vaspin concentrations in obese subjects: modification by insulin resistance. Obesity (Silver Spring) 2010;18:2105-10. [CrossRef]

24. Handisurya A, Riedl M, Vila G, Maier C, Clodi M, Prikoszovich $T$, et al. Serum vaspin concentrations in relation to insulin sensitivity following RYGB-induced weight loss. Obes Surg 2010;20:198-203. [CrossRef]

25. Youn BS, Klöting N, Kratzsch J, Lee N, Park JW, Song ES, et al. Serum vaspin concentrations in human obesity and type 2 diabetes. Diabetes 2008;57:372-7. [CrossRef]

26. Fukuhara A, Matsuda M, Nishizawa M, Segawa K, Tanaka M, Kishimoto $K$, et al. Visfatin: a protein secreted by visceral fat that mimics the effects of insulin. Science 2005;307:426-30.

27. Revollo JR, Körner A, Mills KF, Satoh A, Wang T, Garten A, et al. Nampt/PBEF/Visfatin regulates insulin secretion in beta cells as a systemic NAD biosynthetic enzyme. Cell Metab 2007;6:363-75. [CrossRef]

28. Chen MP, Chung FM, Chang DM, Tsai JC, Huang HF, Shin SJ, et al. Elevated plasma level of visfatin/pre-B cell colony-enhancing factor in patients with type 2 diabetes mellitus. J Clin Endocrinol Metab 2006;91:295-9. [CrossRef] 
29. Dogru T, Sonmez A, Tasci I, Bozoglu E, Yilmaz MI, Genc H, et al. Plasma visfatin levels in patients with newly diagnosed and untreated type 2 diabetesmellitus and impaired glucose tolerance. Diabetes Res Clin Pract 2007;76:24-9. [CrossRef]

30. Berndt J, Klöting N, Kralisch S, Kovacs P, Fasshauer M, Schön $M R$, et al. Plasma visfatin concentrations and fat depot-specific mRNA expression in humans. Diabetes 2005;54:2911-6.

31. López-Bermejo $A$, Chico-Julià $B$, Fernàndez-Balsells $M, \operatorname{Re-}$ casens $M$, Esteve $E$, Casamitjana $R$, et al. Serum visfatin increases with progressive beta-cell deterioration. Diabetes 2006;55:2871-5. [CrossRef]

32. Saddi-Rosa P, Oliveira CS, Giuffrida FM, Reis AF. Visfatin, glucose metabolism and vascular disease: a review of evidence. Diabetol Metab Syndr 2010;2:21. [CrossRef]

33. Leshan RL, Björnholm M, Münzberg $H$, Myers MG Jr. Leptin receptor signaling and action in the central nervous system. Obesity (Silver Spring) 2006;14 Suppl 5:208S-12S. [CrossRef]

34. Tudurí E, Marroquí L, Soriano S, Ropero AB, Batista TM, Piquer
S, et al. Inhibitory effects of leptin on pancreatic alpha-cell function. Diabetes 2009;58:1616-24. [CrossRef]

35. Al-Hamodi Z, Al-Habori M, Al-Meeri A, Saif-Ali R. Association of adipokines, leptin/adiponectin ratio and C-reactive protein with obesityand type 2 diabetes mellitus. Diabetol Metab Syndr 2014;6:99. [CrossRef]

36. Morales A, Wasserfall C, Brusko T, Carter C, Schatz D, Silverstein J, et al. Adiponectin and leptin concentrations may aid in discriminating disease forms in children and adolescents with type 1 and type 2 diabetes. Diabetes Care 2004;27:2010-4.

37. Abdelgadir M, Elbagir M, Eltom M, Berne C, Ahrén B. Reduced leptin concentrations in subjects with type 2 diabetes mellitus in Sudan. Metabolism 2002;51:304-6. [CrossRef]

38. Hartree EF. Determination of protein: a modification of the Lowry method that gives a linear photometric response. Anal Biochem 1972;48:422-7. [CrossRef]

39. Donath MY, Shoelson SE. Type 2 diabetes as an inflammatory disease. Nat Rev Immunol 2011;11:98-107. [CrossRef] 